\title{
Review \\ Bibliometric Analysis of Research on Diesel Pollution in Antarctica and a Review on Remediation Techniques
}

\author{
Zheng Syuen Lim ${ }^{1}{ }^{(D}$, Rasidnie Razin Wong ${ }^{1}\left(\right.$, Chiew-Yen Wong ${ }^{2,3}$, Azham Zulkharnain ${ }^{4}{ }^{(}$, \\ Noor Azmi Shaharuddin ${ }^{1}$ and Siti Aqlima Ahmad 1,3,*(D) \\ 1 Department of Biochemistry, Faculty of Biotechnology and Biomolecular Sciences, Universiti Putra Malaysia, \\ Serdang 43400, Malaysia; syuenylim@gmail.com (Z.S.L.); msrasidnie21@gmail.com (R.R.W.); \\ noorazmi@upm.edu.my (N.A.S.) \\ 2 School of Health Sciences, International Medical University, Kuala Lumpur 57000, Malaysia; \\ WongChiewYen@imu.edu.my \\ 3 National Antarctic Research Centre, B303 Level 3, Block B, IPS Building, Universiti Malaya, \\ Kuala Lumpur 50603, Malaysia \\ 4 Department of Bioscience and Engineering, College of Systems Engineering and Science, \\ Shibaura Institute of Technology, 307 Fukasaku, Minuma-ku, Saitama 337-8570, Japan; \\ azham@shibaura-it.ac.jp \\ * Correspondence: aqlima@upm.edu.my
}

check for updates

Citation: Lim, Z.S.; Wong, R.R.; Wong, C.; Zulkharnain, A.; Shaharuddin, N.A. Ahmad, S.A. Bibliometric Analysis of Research on Diesel Pollution in Antarctica and a Review on Remediation Techniques. Appl. Sci. 2021, 11, 1123. https://dx.doi.org/10.3390/ app11031123

Received: 29 October 2020

Accepted: 7 December 2020

Published: 26 January 2021

Publisher's Note: MDPI stays neutral with regard to jurisdictional claims in published maps and institutional affiliations.

Copyright: (C) 2021 by the authors. Licensee MDPI, Basel, Switzerland. This article is an open access article distributed under the terms and conditions of the Creative Commons Attribution (CC BY) license (https: / / creativecommons.org/ licenses/by/4.0/).
Abstract: Diesel is a fuel commonly used in Antarctica to supply vessels and domestic applications on site. The increasing human activities in the continent consequently have generated high fuel demand, which in turn has increased the occurrence of oil pollution due to accidental events during refueling. A related study received growing interest as more detrimental effects have been reported on Antarctic ecosystems. By adopting the bibliometric analysis, the research on diesel pollution in Antarctica collected in the Scopus database was systematically analysed. An increment in annual publication growth from 1980 to 2019 was observed and two research clusters were illustrated with "hydrocarbons" as the core keyword. Several attempts have been conducted over the past decades to remove anthropogenic hydrocarbon from previous abandoned whaling sites as well as recent oil spill incidents. However, the remote and polar conditions of Antarctica constrained the installation and operation of clean-up infrastructure. This review also briefly encompasses the approaches from past to present on the management of fuel pollution in Antarctica and highlights the potential of phytoremediation as a new bioremediation prospect.

Keywords: Antarctica; diesel pollution; hydrocarbon toxicity; remediation; phytoremediation

\section{Introduction}

Antarctica, the most remote and isolated continent on Earth, has now become a popular research site due to its near-to-pristine and high energy marine ecosystem. Naturally, low level of hydrocarbons in the region due to restricted human activities have made the ecosystem a suitable indicator for the assessment of global hydrocarbon pollution [1,2]. In recent years, mankind's activity has been rising mainly around ice-free coastal areas, which includes national Antarctic programmes, mineral exploitation, tourism and fishing [3,4]. Although the oil pollution across Antarctica is still relatively lower than other regions in the world, the increasing human activity inevitably caused environmental disturbance through the emission of anthropogenic substances.

In response to the hydrocarbon pollution, the extreme nature of Antarctica severely impacts the recovery process, thus making natural attenuation difficult with regard to completely removing hydrocarbon without human interventions. Environmental conditions such as freezing temperature, the freeze-thaw cycle and the presence of ice cause any response to be unfavourable and logistically challenging [3,5]. This paper systematically reviews the research of diesel pollution in Antarctica from 1980 to 2019; popular research 
topics and trends; and a summary on the management of diesel pollution. The aim of this review is to conceptualise the future research trend using bibliometric analysis, as well as to fill the gap in literature on past and current remediation techniques in response to the critical polar environment of Antarctica.

\section{Review Methodology}

This review on diesel pollution in Antarctica and remediation techniques was supported with bibliometric analysis as a systematic approach. Data in the time phase of 1989-2019 were collected from Scopus using the following keyword combination: "Antarctic", "diesel", "oil", "pollution" and "contamination" filtered through article title, abstract and keywords. Data from 2020 were not considered in this study for data consistency. The search result was refined to article-type documents only to minimise false-positive results from duplication. A total of 197 articles were obtained and exported for bibliometric analysis. Two bibliometric software, Biblioshiny and VOSviewer were used; the first was to statistically analyse the descriptive data such as annually scientific production and most frequent keyword, whereas the latter provides visualisation for co-word analysis [6,7].

\section{Diesel Pollution: History and Causes}

Hydrocarbon pollution in Antarctica is mostly concentrated at ice-free coastal areas where nations build their research stations. According to the Council of Managers of National Antarctic Programs (COMNAP), there are currently 76 permanent and seasonal research stations scattered across the continent. Sewage and 'grey water' composed of domestic waste are generated from these research stations, which release anthropogenic hydrocarbon into the Antarctic system [8]. According to ANNEX III Environmental Protocol [9], sewage must not be directly discharged into the sea, but may only be discharged into marine environments that are favourable for initial dilution and rapid dispersal. Hydrocarbon contamination in proximity to the shore is generally caused by local fuel usage and storage for sites like research stations, tourism sites, as well as historic whaling and sealing sites [10].

Fuel spills, as the most common incidents, are recognised by the COMNAP as one of the greatest threats in and around the continent. Such spills occur mainly around research sites where fuel is transported in large quantities as well as aircraft and vehicles are refueled. The most catastrophic spillage incident in the Antarctica history is the grounding of the Bahia Paraiso in Arthur Harbour in 1989, with an estimation of 600,000 L of diesel fuel arctic (DFA) leaked into the ocean within 2-mile radius of Palmer Station [11]. The incident adversely affected the marine life directly and indirectly (Table 1). A vessel ran aground in an incident at Mawson station in 2016 but it was fortunate that no fuel spill was reported [12]. To date, the scale and impacts of oil spills at sea have downsized since the agreement to Antarctic Treaty; however, large-scale coastal clean-up infrastructure does not generally exist in Antarctica.

Table 1. Events in Antarctic and sub Antarctic with reported oil spillage into the marine environment.

\begin{tabular}{|c|c|c|c|c|}
\hline Date & Vessel/Station & Location & Incident and Environmental Impact & Reference \\
\hline December 1983 & Davis station & East Antarctica & $\begin{array}{c}\text { 30,000 L light marine diesel spillage } \\
\text { during station refueling. }\end{array}$ & [13] \\
\hline 3 December 1987 & Nella Dan & Macquarie Island & $\begin{array}{l}\text { Vessel ran aground releasing } 270,000 \mathrm{~L} \\
\text { light marine diesel. Impacts to marine } \\
\text { algae and invertebrates. }\end{array}$ & [14] \\
\hline 28 January 1989 & Bahia Paraiso & $\begin{array}{l}\text { Palmer Station, } \\
\text { Antarctic Peninsula }\end{array}$ & $\begin{array}{l}\text { Vessel sank approximately } 2 \mathrm{~km} \text { offshore } \\
\text { releasing } 600,000 \mathrm{~L} \text { diesel potentially } \\
\text { chronic impacted on flora and fauna. }\end{array}$ & [15] \\
\hline
\end{tabular}


Table 1. Cont.

\begin{tabular}{|c|c|c|c|c|}
\hline Date & Vessel/Station & Location & Incident and Environmental Impact & Reference \\
\hline 18 January 1997 & $\begin{array}{l}\text { Akademik Sergei } \\
\text { Vavilov }\end{array}$ & $\begin{array}{l}\text { Hovgaard, Antarctic } \\
\text { Peninsula }\end{array}$ & $\begin{array}{l}\text { Estimated } 4 \mathrm{~L} \text { of oil and lubricant leaked } \\
\text { from rubber casing resulted from event in } \\
\text { open sea. }\end{array}$ & [16] \\
\hline 28 December 2001 & Vista Mar & $\begin{array}{l}\text { Hope Bay, Antarctic } \\
\text { Peninsula }\end{array}$ & $\begin{array}{l}\text { Propeller damaged during manoeuvring } \\
\text { resulted in gland oil leakage }(<1 \mathrm{~L}) \text {. }\end{array}$ & [17] \\
\hline 23 November 2007 & Explorer & Drake Passage & $\begin{array}{l}\text { Vessel sunk after striking ice. } 210,000 \mathrm{~L} \text { of } \\
\text { oil, petroleum and lubricants spilled. }\end{array}$ & [18] \\
\hline 26 December 2009 & Clelia II & Petermann Island & $\begin{array}{c}\text { Propeller damaged after striking rocks. } \\
\text { Trace amounts of lubricants leaked from } \\
\text { drive shaft. }\end{array}$ & [16] \\
\hline 16 March 2011 & Oliva & $\begin{array}{l}\text { NightingaleIsland, } \\
\text { Trsitan da Cunha } \\
\text { Group }\end{array}$ & $\begin{array}{l}\text { Vessel sunk offshore of rock-hopper } \\
\text { penguin colonies (International Union for } \\
\text { Conservation of Nature, IUCN } \\
\text { Endangered species). Approximately } 1500 \\
\text { tonnes bunker fuel spilled resulted in } \\
\text { widespread oiling of marine vertebrate. }\end{array}$ & [16] \\
\hline
\end{tabular}

Oil spill incidents in Antarctica to date are mostly related to diesel. A recent report by Szopińska et al. [19] identified diesel as the petrogenic source for the presence of polycyclic aromatic hydrocarbons (PAHs) in freshwater samples collected at Admiralty Bay, King George Island, Antarctica. The growing attention in the research of diesel pollution in Antarctica is reflected by the overall publication growth since 1980. Figure 1 depicts the annual scientific publications regarding the discussed topics over the last 40 years, which were grouped according to the consecutive period in decade to avoid flatness in graph. The result showed an increasing trend with an annual growth rate of $5.84 \%$. A spike in publication number was observed in the period of 2000-2009; in fact, the research on diesel pollution in Antarctica has still been expanding until recent years.

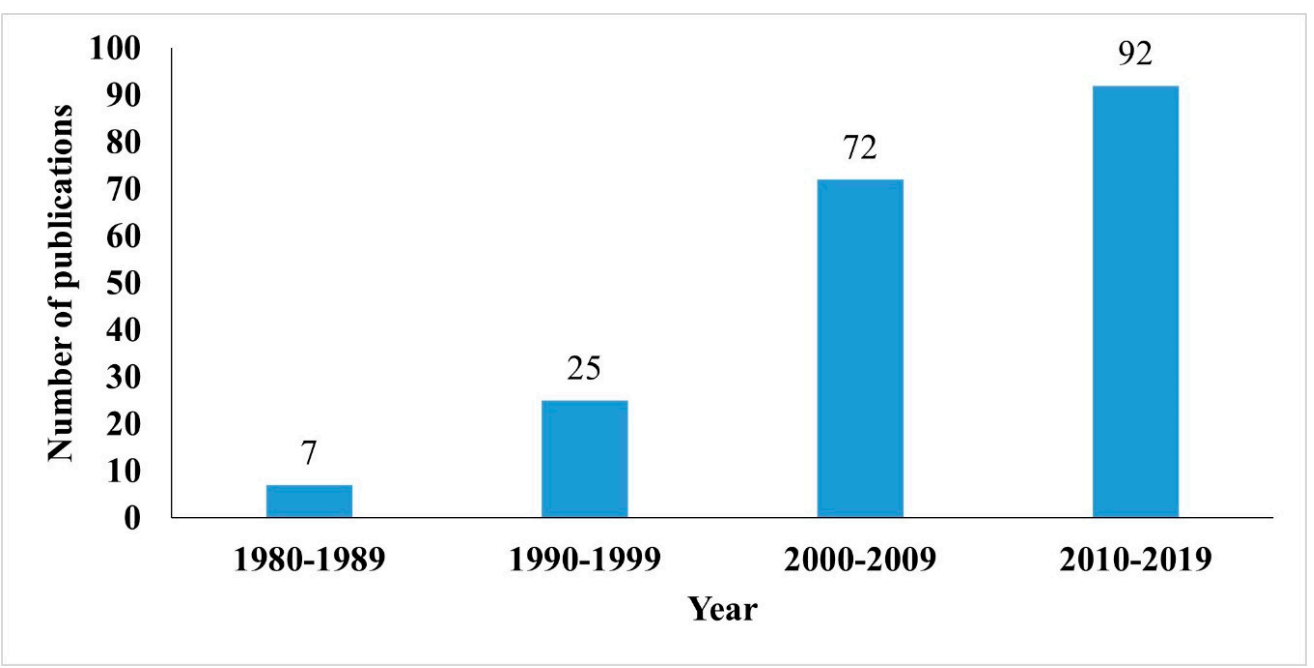

Figure 1. Scientific publications from 1980 to 2019 grouped into four decades.

\section{Research Focus and Trend}

A range of most frequent keywords and co-words were computed using Biblioshiny (Table 2). Co-words are pair of key terms that co-occur within a paper and the analysis was undertaken based on the frequency of co-occurrence. This approach enables researchers to postulate the knowledge structure and significant topics in the current research field. In this study, top-ranked keywords from both categories showed a degree of similarity. The exam- 
ples were hydrocarbon, polycyclic aromatic hydrocarbon (PAH), toxicity, biodegradation, bioremediation and bacteria.

Table 2. Descriptive analysis: top 15 most frequent keywords and co-words in descending order.

\begin{tabular}{cccc}
\hline Keyword & $\begin{array}{c}\text { No. of } \\
\text { Article }\end{array}$ & Co-Word & $\begin{array}{c}\text { No. of } \\
\text { Article }\end{array}$ \\
\hline Soil pollution & 98 & hydrocarbons & 66 \\
Biodegradation & 92 & soil pollution & 60 \\
Bioremediation & 87 & bioremediation & 56 \\
Hydrocarbon & 81 & oil spill & 50 \\
Environmental monitoring & 63 & biodegradation & 44 \\
Oil spill & 62 & environmental monitoring & 42 \\
Toxicity & 36 & controlled study & 34 \\
Bacterium & 34 & bacteria (microorganism) & 32 \\
Controlled study & 34 & chemistry & 30 \\
Soil & 34 & toxicity & 27 \\
Polycyclic aromatic hydrocarbon & 31 & concentration (composition) & 26 \\
(PAH) & 31 & sediment & 26 \\
Water pollutant & 30 & water pollutants, chemical & 26 \\
Chemistry & 29 & PAH & 24 \\
Sediment & 26 & animals & 22 \\
\hline Concentration (composition) & &
\end{tabular}

Diesel hydrocarbon composition is one of the study focus as winter diesel is treated apart from normal fuel refinery. High molecular weight paraffins with limited solubility are prone to wax crystal precipitation when the fuel cools down. To prevent gelling of diesel in cold temperature, high molecular weight paraffins are selectively reduced in diesel to lower its density and viscosity [20]. Due to different origin of crude, refinery and post-processing treatment, commonly used winter diesels such as Special Antarctic Blend diesel (SAB), marine gas oil (MGO) and intermediate grade of fuel oil 180 (IFO 180) contain varying hydrocarbon compositions formulated for use in the Antarctic conditions.

$\mathrm{SAB}$ is the most used fuel at the Antarctic and sub-Antarctic regions (i.e., Australian Antarctic research stations) with an annual consumption of 2 million litres [21]. It is a middle distillate containing $96 \%$ volatile compounds, primarily alkanes in the range $n$ - $C_{9-14}$ and other branched alkanes, cycloalkanes as well as aromatic hydrocarbons. Both SAB and MGO are similar in density and viscosity, but MGO is composed of $n-C_{9-25}$ range of alkanes. IFO 180 is a heavier complex mixture of mainly residual oil and middle distillate constituting $6 \%$ to $7 \%$ of the fuel. The composition of an IFO 180 includes a wide carbon range of $\mathrm{C}_{6}$ to $>n-\mathrm{C}_{-40}$ and may contain PAHs from cracked components, hence is the densest [22].

Diesel toxicity is another hot topic that is usually addressed with hydrocarbon composition. Certain proportions of the hydrocarbon compounds are able to produce a wateraccommodated fraction (WAF) when in contact with water [23]. The bioavailability of WAF towards marine organisms is attributed to the ecological impacts of oil spillage. According to the thesis published by Brown [10] that examined the chemical behaviour, composition and toxicity of WAF, SAB has the highest magnitude of acute toxicity on marine organisms, whereas MGO and IFO 180 are generally more toxic than SAB upon longer exposure due to their higher proportion of high molecular weight PAHs. Aromatic hydrocarbons are more water-soluble than saturated alkanes of similar molecular weight, hence are regarded as major toxicity agents.

Monocyclic aromatic hydrocarbons including benzene, toluene, ethyl benzene and xylene (BTEX) are the most water-soluble, therefore easing the migration and dispersion in the environment and cells [24]. In temperate regions, BTEX is highly volatile but the low Antarctic temperature exacerbates surface evaporation in polluted sites. The molecular diffusion of BTEX is greatly reduced, causing the contact time with water to be relatively longer. Ultimately, the ratio of dissolved to evaporated hydrocarbons increases, which 
imposes a huge threat to the Antarctic aquatic life [10]. Meanwhile, PAHs of higher molecular weight have lesser acute toxicity due to their lower solubility, but their persistence is much greater than that of lighter fractions. PAHs are lipophilic, which enhances the adsorption to organic matter and they tend to bio-accumulate in lipid tissue of organism leading to chronic effects [25]. The study of McGrath and Di Toro [26] reported the narcosis effect of PAHs in which toxicity could be photoenhanced upon ultraviolet radiation on cellular tissues.

Environmental monitoring in Antarctic research covers a diverse range of toxicology studies on marine organisms, invertebrates, birds and plants. Local mortality of intertidal marine invertebrates and long-term impact on bird population have been reported on most oil spill incidents. The acute and chronic exposure and sublethal effect on mortality, growth and reproduction of meiofauna communities have been investigated in field $[27,28]$ and laboratory tests [29]. Toxicity responses of these organisms towards hydrocarbon compounds are species-specific, which can also correspond to their life stages. Stark et al. [28] reported on the differences in Antarctic nematodes and copepods abundance upon diesel treatment in a five-year field experiment at Casey Station, East Antarctica. Nematodes were seen to be more sensitive to hydrocarbons compared to copepods, showing a sharp decline in abundance in the early stage. Nevertheless, both meiofaunal organisms were negatively impacted by the effect of hydrocarbon and were likely to persist for more than five years or show little recovery in community structure.

The toxicity of hydrocarbon on plants can be observed through morphological characteristics such as germination, root and shoot growth, photosynthetic efficiency and chlorophyll content. Hydrocarbon contamination induces inhibitory effect on plant early life cycle that results in delayed germination as well as slow root and shoot growth rate [21,27]. It also reduces the photosynthetic efficiency of Antarctic mosses and algae, but is relatively less sensitive and less severe compared to cases reported on marine invertebrates [30]. A mechanism has been proposed where the lipophilic hydrocarbons increase plant membrane permeability, hence are prone to chloroplast and/or thylakoid membranes disruption.

Based on the co-occurrence analysis network in Figure 2, the study on diesel hydrocarbons and toxicity falls into two research clusters with "oil spill" and "hydrocarbons" as core keywords. The mapping of co-occurrence keywords showed the co-word interaction, which enabled the conceptualisation of thematic area. The items displayed in the network were the selected keywords that met the threshold of minimum occurrence of 5 in publications. The size of the circle and label indicates the frequency of appearance in publications, while the thickness of the line represents the co-occurrence linking strength between two keywords. Two major clusters were illustrated with distinct colours suggesting red for environmental monitoring and green for remediation mechanisms as central research themes. "Hydrocarbons" was the most frequently used co-word in publications and closely linked to "soil pollution", "biodegradation" and "oil spill". From the keyword "oil spill", the research theme branched out into another cluster consisting "chemistry", "toxicity", "concentration (composition)", "controlled study" and a few others that are relevant to environmental monitoring. Detailed chemical analysis provided a groundwork for toxicology enabling better assessment of environmental risk. On the other hand, a strong correlation can be observed between "biodegradation" with "bacteria". Since the Antarctic Treaty forbids the importation of foreign organisms into the continent, the biological functioning of indigenous microbial communities has received widespread attention. Throughout the years, the microbial application in bioremediation has been proven effective and hence, more advanced methods and technology were employed to achieve optimal results. The research findings are discussed in the following section on bioremediation. 


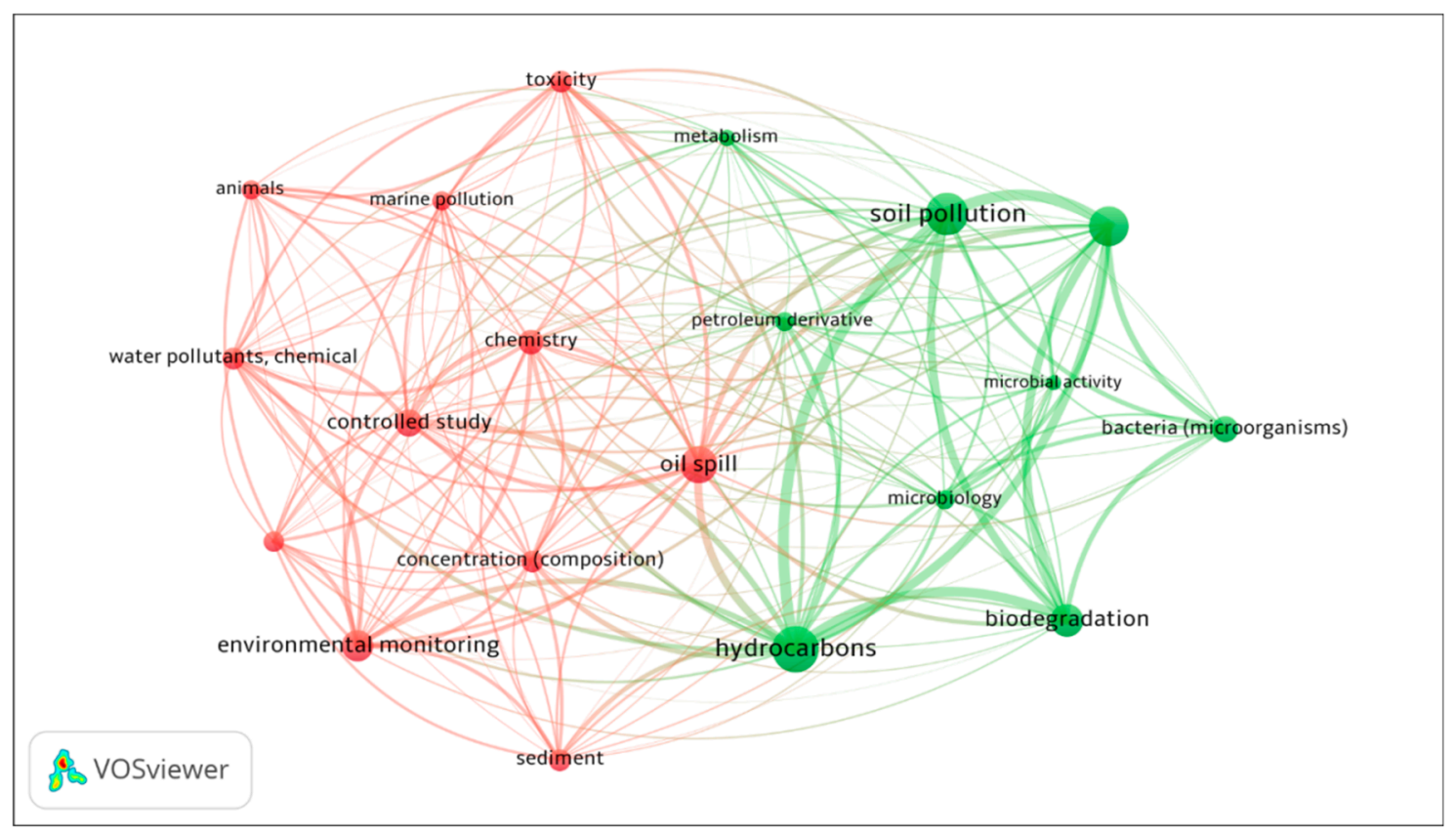

Figure 2. Co-occurrence network in the research field. Co-words are mapped into two major clusters implying the research themes (red: environmental monitoring; green: remediation mechanism).

\section{Remediation Techniques: Physical, Chemical and Biological Approaches}

Following an oil spill, natural attenuation is the first approach to control the worsening of the situation. Natural attenuation is the reduction of contaminant mass, volume, concentration, mobility and toxicity through a variety of physical, chemical and biological processes under favourable conditions without human intervention [31]. This process eliminates most of the lighter chain hydrocarbons, which is however inadequate for PAHs [32]. A long timeframe is required to remove significant level of contaminants for no external force involved to expedite the process. With very low rates of degradation achieved in the cold Antarctic environment, a broad spectrum of remediation techniques was introduced classified into physical, chemical and biological methods.

Physical treatment effectively controls oil spills in a water environment through two main steps: containment and recovery. Equipment such as oil boomer and skimmer serve as a barrier to trap the oil and prevent it from spreading. After skimmer operation, oleophilic adsorbents are used to remove the remaining oil that can soak as much as 70 times their weight in oil depending on their material [33]. In situ burning is another method that is able to remove up to $98 \%$ of the oil spill. The oil slick on the sea surface has to be above a threshold of thickness (around $3 \mathrm{~mm}$ ) to be possibly ignited into flame and kept under control within the polluted site. These applications are still limited to rough sea wave and high wind velocity [34].

A chemical remediation method is more applicable as an emergency response when the sea condition is too rough for mechanical methods. Chemicals such as dispersant are sprayed over the sea surface by aircraft to enhance the mixing of oil and water into smaller oil droplets. This dispersant contains surfactant accountable for breaking up the oil slick, and aims to reduce the immediate risk to marine life. However, the chemical clean-up attempt is still controversial as it may impose a huge negative impact on benthic organisms. Rico-Martínez et al. [35] reported that the combination of dispersant Corexit 9500A and oil magnified the toxicity on B. manjavacas by 52 -fold. The research by Elarbaoui et al. [36] concluded that the application of dispersants alone showed a toxic effect on copepods and nematodes and, meanwhile, the chemically dispersed oil did not impose a greater harm.

Environmental-friendliness and cost savings are the major concerns for all remediation techniques. Bioremediation, which relies on biological mechanism to reduce (degrade, 
detoxify, mineralise or transform) the concentration of pollutants to an innocuous state, is adopted in the field to manage the Antarctic spill sites like Casey Station [37]. As the Antarctic Treaty forbids the importation of foreign organisms into the Antarctic, indigenous organisms proven with hydrocarbon-degrading ability play a major role in ecosystem recovery. Effective bioremediation is dependent on the features of the treatment site such as soil texture, climate variables, water availability as well as existing vegetation and terrain topology [38]. In general, bioremediation can be carried out ex situ and in situ depending on the resource availability.

\section{Bioremediation: Feasibility and Limits}

Nutrient limitation in Antarctic soils is one of the biggest constraints in bioremediation. Most Antarctic soils are oligotrophic and particularly low in nitrogen and phosphorous content, except highly localized coastal soils, sites of penguin rookeries and elephant seal colonies [39]. A stoichiometric imbalance occurs when a significant amount of hydrocarbon is spilled on these soils. Ex situ bioremediation techniques which mimic the environment condition of the indigenous or transient microbes can be enhanced by incorporating applications such as aeration, irrigation and nutrients as well as leachate collection systems to achieve maximum degradation rate [40]. As the C:N:P ratio in Antarctic soils moves away from the optimal index that promotes microbial growth, the application of a nutrientamended bio-pile to contaminated soil is widely used at polar regions such as Casey Station, Antarctica [41]. In a study on crude oil bioremediation in intertidal sediments, pristine soils were artificially contaminated with Arabian light crude oil (topped at $150{ }^{\circ} \mathrm{C}$ ) in several $1 \mathrm{~m}^{2}$ enclosures and treated with different fertilisers for one year [42]. The result only showed enhanced biodegradation efficiency on $n$-alkanes in the first three months on fertilised plots and reached the same level of biodegradation with the unfertilised control in the following months. Similar biostimulation methods using Inipol EAP 22 evidenced a positive effect on two sub-Antarctic soil samples (organic and mineral soils) in mesocosm experiments for two months [43]. Inipol EAP 22 is a slow-release commercial oleophilic fertiliser containing a solution of urea, oleic acid and lauryl phosphate. The authors attributed the enhanced hydrocarbon biodegradation to the stimulatory effect of fertilisers in hydrocarbon-degrading microbe abundance. The result was especially pronounced in mineral soil with more than three orders of magnitude higher in terms of biostimulation efficiency. Nonetheless, excessive nitrogen addition can cause inhibitory effect on microbial growth and lower degradation rate due to osmotic soil water potential depression. In line with this, Walwoth et al. [44] studied the optimal nitrogen addition at $604 \mathrm{mg} \mathrm{N} \mathrm{kg}^{-1} \mathrm{H}_{2} \mathrm{O}$ and inhibition threshold of $1200 \mathrm{mg} \mathrm{N} \mathrm{kg}^{-1} \mathrm{H}_{2} \mathrm{O}$ for petroleum-contaminated soil collected from Macrquarie Island.

Similar experimental designs can produce varying results depending on the previous history of pollution and soil properties. This was evidenced by two different findings using a similar fertiliser protocol of complex organic matrix (fish meal and commercial fertiliser, OSE II) at Carlini Station, King George Island. With the enhancement of fish meal in biopile, a significant loss of $71 \%$ of total hydrocarbon concentration was reported in 2010 [45]. In addition, a shift in bacterial structure was observed over 50 days of incubation. The treated sample was a chronically diesel-contaminated soil exposed to fresh hydrocarbon contamination. The predominant phylum, Proteobacteria, was overtaken by Actinobacteria, which adapted better to lower levels of available hydrocarbons and depleted nutrient concentrations. Both bacteria groups are among the frequently reported hydrocarbon-degraders in polar soils [46,47]. In contrast with the finding, similar field trial in year 2007 suggested unspecific fish meal-induced soil microbiota growth that did not promote differential growth of hydrocarbon-degrading microbes [48]. Hydrocarbon reduction on aged diesel-contaminated soil was reported to be insignificant in the fish meal amended system compared to the control system at the end of the assay. Conversely, the application of OSE II produced a significant hydrocarbon reduction after 45 days. The efficiency of the salt-mediated system in bioremediation was also not discerned despite 
proof from previous study [49]. Different soil contamination histories accounted for the divergence in the two findings.

A bioreactor is another popular ex situ technique that can effectively reduce bioremediation time by monitoring process parameters including temperature, $\mathrm{pH}$, agitation and substrate concentrations. Five operating modes of bioreactors include batch, fed-batch, sequencing batch, continuous and multistage. In fact, the use of bioreactors for remediation purpose in Antarctic research has not been reported thus far despite being proven to have great biodegradation efficiency for volatile compounds and recalcitrate hydrocarbon species in many studies [50-52]. Some recent data on statistical optimisation for bacterial growth conditions along with hydrocarbon degradation using Antarctic microbes in laboratory-based study were published [53-55]. The relationships of multiple rate-limiting factors were evaluated using response surface methodology to obtain optimised conditions. These established findings can be employed to the best advantage by adopting bioreactor system that provides excellent control of bioprocess parameters. Ex situ bioremediation techniques are favourable to treat low permeability and the heterogeneous nature of soil [56]. However, the excavation process is relatively laborious and demands higher cost compared to in situ bioremediation.

In situ bioremediation is the on-site management of pollutants that requires no excavation, thus leading to little or zero disturbance to soil structure. Preliminary tests such as lab-scale and pilot-scale systems are essential in this technique to ensure safe and efficient remediation. According to the Madrid Protocol, remediation operations shall not result in any greater adverse environmental impacts than the "do nothing" approach. One of the complications in field study is the formation of a non-aqueous-phase liquid body when infiltration of hydrocarbons into the subsurface soils occurs after a large spill [10]. Compared to the heavy hydrocarbons present at the soil surface subjected to aerobic condition, the subsurficial hydrocarbons are less susceptible to degradation. The application of bioventing mitigates the issue by incorporating air injection. This remedial approach involves delivering oxygen to the unsaturated zone to stimulate airflow, which in turn increases microbial activity for biodegradation [40]. A study reported that microbioventing using nine small injection rods ( $0.5 \mathrm{~m}$ apart) was more efficient in enhancing biodegradation than single-well bioventing as the distribution of oxygen is more uniform [57]. Aside from that, a shallow water table and thin soil cover also contributed to the inefficiency of single-well bioventing in hydrocarbon removal. The important roles of airflow rates and air intervals were described.

Complex microbial interactions as well as the co-contamination of heavy metals and hydrocarbon have the potential to render in situ bioremediation unsuccessful. Hence, thorough prior studies of contaminated sites ex situ are significant including soil analysis, molecular screening and microbial isolation, as well as preliminary studies involving microcosms. Subsequent trials of mesocosms and macrocosms are recommended as laboratorybased study may not precisely reflect the observations in the field for the large-scale soil microbial interactions [58]. The freeze-thaw cycle is another pitfall that causes dissolved contaminants to be mobilised in surface and subsurface soils besides disrupting the nutrient distribution upon thawing. As bioremediation is more conventionally practiced and assessed for its efficiency, the goal to achieve a practical strategy should consider sitespecific conditions and acceptable cost-time relationship. For instance, integrated remedial approaches (coupling solvent extraction and bioremediation), application of biosurfactant and algae-bacteria consortia are among the intriguing prospects [59-61].

\section{Bioremediation: Microbial Pathway}

As mentioned, microbes are involved in most bioremediation techniques as they are easy to maintain with feasible application. The adoption of cold-adapted microbes in degrading diesel has shown great efficacy in various research works $[54,55]$. Rhodococcus, Pseudomonas and Sphingomonas are among the common bacterial species dominating the oil-polluted Antarctic environment and contributing to the mineralisation of hydrocar- 
bon [62-64]. Roslee et al. [55] reported on microbial application in bioremediation and the factors limiting the rate of degradation including temperature and availability of nutrients, oxygen and contaminants. The ability of bacteria to degrade hydrocarbon, even the most persistent PAHs, is proposed primarily through the aerobic metabolic pathway (Figure 3).

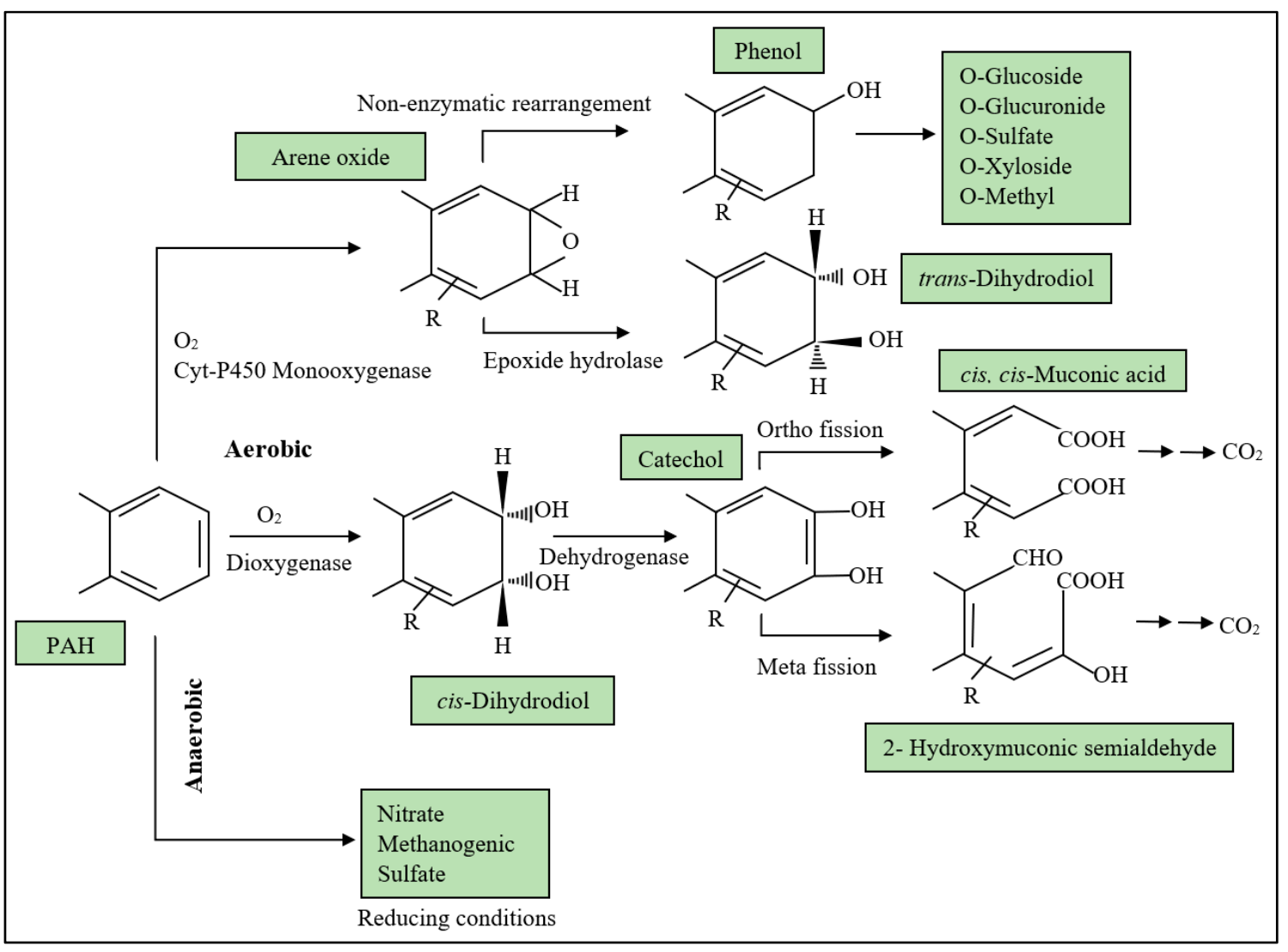

Figure 3. Proposed pathways for microbial catabolism of PAH (adapted [65]).

The importance of oxygen as a key electron acceptor in the microbial system has been postulated; hence, the system was later developed to employ microalgae to complement the oxygen demand via the photosynthetic cycle. Algae-bacteria consortia establish a symbiotic relationship described by Fu and Secundo [61] as an ideal self-sustaining system. Effective synergism and improved hydrocarbon degradation have been reported with varying degrees of success using different consortia. A co-culture of B. cepacia and freshwater algae performed $99 \%$ total petroleum hydrocarbon removal and exhibited higher tolerance upon phenol loading [66]. The robustness of microbial bioremediation co-stimulated with algal culture has sparked the study of axenic algae in phytoremediation, one of the enhanced in situ bioremediation techniques.

\section{Phytoremediation}

Phytoremediation relies on the use of plants to mitigate the toxicity of pollutants. The extensive application of phytoremediation can be generally classified into seven mechanisms; phytoextraction, phytovolatilisation, phytodegradation, rhizodegradation, rhizofiltration, phytostabilisation and hydraulic control based on the parts of plants involved and the effects on contaminants [67]. Remediation of organic pollutants are predominantly by degradation, containment and volatilisation [68]. The resource-rich root exudate of plants stimulates active microbial activity that in turns enhances the degradation of contaminants as previously described in microbe-algae consortia systems. In fact, the ability of higher plants with extensive fibrous root system to accumulate petroleum hydrocarbon independently has been well studied in tropical regions (i.e., legumes and grasses). These plants 
were highlighted to have the capacity to absorb, immobilise and transform the organic and inorganic toxicants within the rhizosphere. Studies on non-leguminous and lower plants such as algae and moss are relatively limited; however, a few reports have validated algae as a potential degrader.

Semple et al. [69] suggested that eukaryotic algae are capable of biotransforming aromatic compounds sequentially into hydroxylated intermediates, leading to overall degradation of the pollutants. PAH biodegradation was tested on the microalgae S. captricornutum showing 78\% fluoranthene removal upon 7 days of treatment [70]. Besides the ability to uptake hydrocarbons in plant metabolism, Antarctic moss and algae demonstrated a high tolerance towards SAB fuel, which contrasts strongly with the high sensitivities reported for indigenous microbial communities and invertebrates [30]. The heterotrophic mode of algae to metabolise a diverse range of hydrocarbon has been suggested to be associated with the habitat where the Antarctic algae receive minimal irradiance below the ice sheet.

Although biochemical mechanisms employed by these algae are not elucidated well, the first report of a purely algal biotransformation of diaryl ethers by Todd, Cain and Schmidt [71] proposed a possible mechanism involving mono- and di-oxygenase pathways in prokaryotic and eukaryotic microalgae. The hypothesis was supported by the formation of monohydroxylated derivatives suggesting the use of cytochrome P-450 monooxygenase in the obligate presence of oxygen. Meanwhile, the dioxygenase pathway was implicated through the route via cis-dihydrodiols that resembled the fungus.

\section{Conclusions}

Diesel pollution in Antarctica attracts great concern for its deleterious environmental impacts. Oil spill management needs to be monitored as the response time is longer in polar regions for similar remediation techniques applied in temperate regions. Among all possible techniques employed to attenuate diesel pollution, phytoremediation has steadily emerged in the area of research over the past two decades but still remains relatively marginal. Nevertheless, the capability of algae to degrade a diverse range of hydrocarbons either independently or in synergy with microbes in temperate regions has been proven in many studies. Algae, as the most abundant photosynthetic organisms in Antarctica, constitute the basis of the food web and hence serve a fundamental role in the ecosystem. The discovery of Antarctic algae in degrading diesel independently would be pivotal for other noble findings besides contributing a new sustainable bioremediation practice.

Author Contributions: Writing-original draft preparation, Z.S.L.; Writing-review and editing, S.A.A., R.R.W., C.-Y.W., A.Z. and N.A.S.; Supervision, S.A.A., C.-Y.W., N.A.S. and A.Z. All authors have read and agreed to the published version of the manuscript.

Funding: This research was funded by Universiti Putra Malaysia, Matching Grant Putra 9300436 and Putra Berimpak 9678900 and Yayasan Penyelidikan Antartika Sultan Mizan (YPASM) Research Grant 2020 on "Phytoremediation Potential of Antarctic Microalgae on Diesel Hydrocarbons".

Acknowledgments: The authors would like to thank Universiti Putra Malaysia, International Medical University, Sultan Mizan Antarctic Research Foundation and National Antarctic Research Centre. This paper also contributes to the international SCAR research programme 'State of the Antarctic Ecosystem'.

Conflicts of Interest: The authors declare no conflict of interest.

\section{References}

1. Cripps, G. Natural and anthropogenic hydrocarbons in the Antarctic marine environment. Mar. Pollut. Bull. 1992, 25, 266-273. [CrossRef]

2. Tengku-Mazuki, T.A.; Subramaniam, K.; Zakaria, N.N.; Convey, P.; Khalil, K.A.; Lee, G.L.Y.; Zulkharnain, A.; Shaharuddin, N.A.; Ahmad, S.A. Optimization of phenol degradation by Antarctic bacterium Rhodococcus sp. Antarct. Sci. 2020, 32, 486-495. [CrossRef]

3. Raymond, T.; King, C.; Stark, J.; Snape, I. Oil Pollution in Antarctica. In Oil Spill Science and Technology, 2nd ed.; Fingas, M., Ed.; Gulf Professional Publishing: Houston, TX, USA, 2017; pp. 759-803. ISBN 978-0-120809413-6. 
4. Subramaniam, K.; Ahmad, S.A.; Shaharuddin, N.A. Mini review on phenol biodegradation in Antarctica using native microorganisms. Asia Pac. J. Mol. Biol. Biotechnol. 2020, 28, 77-89. [CrossRef]

5. Abdulrasheed, M.; Zakaria, N.N.; Roslee, A.F.A.; Shukor, M.Y.; Zulkharnain, A.; Napis, S.; Convey, P.; Alias, S.A.; GonzalezRocha, G.; Ahmad, S.A. Biodegradation of diesel oil by cold-adapted bacterial strains of Arthrobacter spp. from Antarctica. Antarct. Sci. 2020, 1-13. [CrossRef]

6. Aria, M.; Cuccurullo, C. bibliometrix: An R-tool for comprehensive science mapping analysis. J. Inf. 2017, 11, 959-975. [CrossRef]

7. Van Eck, N.J.; Waltman, L. Software survey: VOSviewer, a computer program for bibliometric mapping. Scientometrics 2010, 84, 523-538. [CrossRef] [PubMed]

8. Tin, T.; Fleming, Z.L.; Hughes, K.A.; Ainley, D.G.; Convey, P.; Moreno, C.A.; Pfeiffer, S.; Scott, J.; Snape, I. Impacts of local human activities on the Antarctic environment. Antarct. Sci. 2009, 21, 3-33. [CrossRef]

9. Antarctic Treaty Consultative Parties. ANNEX III to the Protocol on Environmental Protection to the Antarctic Treaty; Her Majesty's Stationery Office: London, UK, 1991.

10. Brown, D.M.; Bonte, M.; Gill, R.; Dawick, J.; Boogaard, P.J. Heavy hydrocarbon fate and transport in the environment. Q. J. Eng. Geol. Hydrogeol. 2017, 50, 333-346. [CrossRef]

11. Sweet, S.T.; Kennicutt, M.C.; Klein, A.G. The grounding of the Bahía Paraíso, Arthur Harbor, Antarctica. In Handbook of Oil Spill Science and Technology; Fingas, M., Ed.; John Wiley \& Sons, Inc.: Hoboken, NJ, USA, 2015; pp. 547-556. ISBN 978-0-470-45551-7.

12. BBC News. Aurora Autsralis: Antarctica Icebreaker Passengers Rescued. Autsralia BBC News, 26 February 2016.

13. Woehler, E.J.; Johnstone, G.W. Status and Conservation of the Seabirds of the Australian Antarctic Territory. In Seabird Status and Conservation: A Supplement; Croxall, J.P., Ed.; International Council for Bird Preservation: Cambridge, UK, 1991; pp. 279-308. ISBN 9780946888191.

14. Smith, S.D.A.; Simpson, R. Effects of the 'Nella Dan' oil spill on the fauna of Durvillaea antarctica holdfasts. Mar. Ecol. Prog. Ser. 1995, 121, 73-89. [CrossRef]

15. Penhale, P.; Coosen, J.; Marshoff, E.R. The Bahia Paraiso: A Case Study in Environmental Impact, Remediation and Monitoring. In Antarctic Communities: Species, Structure and Survival; Battaglia, B., Valencia, J., Walton, D.W.H., Eds.; Cambridge University Press: Cambridge, UK, 1997; pp. 444-457.

16. Ruoppolo, V.; Woehler, E.J.; Morgan, K.; Clumpner, C.J. Wildlife and oil in the Antarctic: A recipe for cold disaster. Polar Rec. 2012, 49, 97-109. [CrossRef]

17. Liggett, D.; McIntosh, A.; Thompson, A.; Gilbert, N.; Storey, B. From frozen continent to tourism hotspot? Five decades of Antarctic tourism development and management, and a glimpse into the future. Tour. Manag. 2011, 32, 357-366. [CrossRef]

18. Kesselly, B. Report of Investigation in the Matter of Sinking of Passenger Vessel EXPLORER (O.N. 8495$) 23$ November 2007 in the Bransfield Strait Near the South Shetland Islands; The Bureau of Maritime Affairs: Monrovia, Liberia, 2009.

19. Szopińska, M.; Szumińska, D.; Bialik, R.J.; Dymerski, T.; Rosenberg, E.; Polkowska, Ż. Determination of polycyclic aromatic hydrocarbons (PAHs) and other organic pollutants in freshwaters on the western shore of Admiralty Bay (King George Island, Maritime Antarctica). Environ. Sci. Pollut. Res. 2019, 26, 18143-18161. [CrossRef] [PubMed]

20. Bennett, J. Advanced fuel additives for modern internal combustion engines. In Alternative Fuels and Advanced Vehicle Technologies for Improved Environmental Performance; Folkson, R., Ed.; Woodhead Publishing: Cambridge, UK, 2014; pp. 165-194. ISBN 9780857095220.

21. Macoustra, G.K.; King, C.K.; Wasley, J.; Robinson, S.A.; Jolley, D.F. Impact of hydrocarbons from a diesel fuel on the germination and early growth of subantarctic plants. Environ. Sci. Process. Impacts 2015, 17, 1238-1248. [CrossRef] [PubMed]

22. Brown, K.E.; King, C.K.; Kotzakoulakis, K.; George, S.C.; Harrison, P.L. Assessing fuel spill risks in polar waters: Temporal dynamics and behaviour of hydrocarbons from Antarctic diesel, marine gas oil and residual fuel oil. Mar. Pollut. Bull. 2016, 110, 343-353. [CrossRef]

23. Singer, M.; Aurand, D.; Bragin, G.; Clark, J.; Coelho, G.; Sowby, M.; Tjeerdema, R. Standardization of the Preparation and Quantitation of Water-accommodated Fractions of Petroleum for Toxicity Testing. Mar. Pollut. Bull. 2000, 40, 1007-1016. [CrossRef]

24. Sirotkin, A.V. Reproductive Effects of Oil-Related Environmental Pollutants. In Encyclopedia of Environmental Health, 2nd ed.; Nrigau, J., Ed.; Elsevier: Amsterdam, The Netherlands, 2018; pp. 493-498.

25. Abdel-Shafy, H.I.; Mansour, M.S. A review on polycyclic aromatic hydrocarbons: Source, environmental impact, effect on human health and remediation. Egypt. J. Pet. 2016, 25, 107-123. [CrossRef]

26. McGrath, J.A.; Di Toro, D.M. Validation of the Target Lipid Model for Toxicity Assessment of Residual Petroleum Constituents: Monocyclic and Polycyclic Aromatic Hydrocarbons. Environ. Toxicol. Chem. 2009, 28, 1130-1148. [CrossRef]

27. Naidoo, K. The Effects of Petroleum Hydrocarbon Contamination on Selected Intertidal Macrophytes and Meiofauna. Ph.D. Thesis, University of KwaZulu-Natal, Durban, South Africa, 2015.

28. Stark, J.S.; Mohammad, M.; McMinn, A.; Ingels, J. The effects of hydrocarbons on meiofauna in marine sediments in Antarctica. J. Exp. Mar. Biol. Ecol. 2017, 496, 56-73. [CrossRef]

29. Lewis, C.; Pook, C.; Galloway, T.S. Reproductive toxicity of the water accommodated fraction (WAF) of crude oil in the polychaetes Arenicola marina (L.) and Nereis virens (Sars). Aquat. Toxicol. 2008, 90, 73-81. [CrossRef]

30. Nydahl, A.C.; King, C.K.; Wasley, J.; Jolley, D.F.; Robinson, S.A. Toxicity of fuel-contaminated soil to Antarctic moss and terrestrial algae. Environ. Toxicol. Chem. 2015, 34, 2004-2012. [CrossRef] 
31. Lu, J. Identification of Forensic Information from Existing Conventional Site-Investigation Data. In Introduction to Environmental Forensics, 3rd ed.; Murphy, B.L., Morrison, R.D., Eds.; Academic Press: Cambridge, MA, USA, 2015; pp. 149-164. ISBN 978-0-12-404696-2.

32. García-Delgado, C.; Alfaro-Barta, I.; Eymar, E. Combination of biochar amendment and mycoremediation for polycyclic aromatic hydrocarbons immobilization and biodegradation in creosote-contaminated soil. J. Hazard. Mater. 2015, 285, 259-266. [CrossRef] [PubMed]

33. Tewari, S.; Sirvaiya, A. Oil spill remediation and its regulation. Int. J. Res. Sci. Eng. 2015, 1, 1-7.

34. Obi, E.O.; Kamgba, F.A.; Obi, D.A. Techniques of Oil Spill Response in the sea. IOSR J. Appl. Phys. 2014, 6, 36-41. [CrossRef]

35. Rico-Martinez, R.; Snell, T.W.; Shearer, T.L. Synergistic toxicity of Macondo crude oil and dispersant Corexit $9500 A ® t o$ the Brachionus plicatilis species complex (Rotifera). Environ. Pollut. 2013, 173, 5-10. [CrossRef] [PubMed]

36. Elarbaoui, S.; Richard, M.; Boufahja, F.; Mahmoudi, E.; Thomas-Guyon, H. Effect of crude oil exposure and dispersant application on meiofauna: An intertidal mesocosm experiment. Environ. Sci. Process. Impacts 2015, 17, 997-1004. [CrossRef] [PubMed]

37. McWatters, R.; Wilkins, D.; Spedding, T.; Hince, G.; Raymond, B.; Lagerewskij, G.; Terry, D.; Wise, L.; Snape, I. On site remediation of a fuel spill and soil reuse in Antarctica. Sci. Total Environ. 2016, 571, 963-973. [CrossRef] [PubMed]

38. Álvarez, L.M.M.; Ruberto, L.; Balbo, A.L.; Mac Cormack, W.P. Bioremediation of hydrocarbon-contaminated soils in cold regions: Development of a pre-optimized biostimulation biopile-scale field assay in Antarctica. Sci. Total Environ. 2017, 591, 194-203. [CrossRef]

39. Ortiz, M.; Bosch, J.; Coclet, C.; Johnson, J.; Lebre, P.; Salawu-Rotimi, A.; Vikram, S.; Makhalanyane, T.P.; Cowan, D.A. Microbial Nitrogen Cycling in Antarctic Soils. Microorganisms 2020, 8, 1442. [CrossRef]

40. Azubuike, C.C.; Chikere, C.B.; Okpokwasili, G.C. Bioremediation techniques-classification based on site of application: Principles, advantages, limitations and prospects. World J. Microbiol. Biotechnol. 2016, 32, 1-18. [CrossRef]

41. Whelan, M.; Coulon, F.; Hince, G.; Rayner, J.; McWatters, R.; Spedding, T.; Snape, I. Fate and transport of petroleum hydrocarbons in engineered biopiles in polar regions. Chemosphere 2015, 131, 232-240. [CrossRef]

42. Pelletier, É; Delille, D.; Delille, B. Crude oil bioremediation in sub-Antarctic intertidal sediments: Chemistry and toxicity of oiled residues. Mar. Environ. Res. 2004, 57, 311-327. [CrossRef] [PubMed]

43. Delille, D.; Coulon, F. Comparative Mesocosm Study of Biostimulation Efficiency in Two Different Oil-Amended Sub-Antarctic Soils. Microb. Ecol. 2007, 56, 243-252. [CrossRef] [PubMed]

44. Walworth, J.L.; Pond, A.; Snape, I.; Rayner, J.; Ferguson, S.; Harvey, P. Nitrogen requirements for maximizing petroleum bioremediation in a sub-Antarctic soil. Cold Reg. Sci. Technol. 2007, 48, 84-91. [CrossRef]

45. Dias, R.L.; Ruberto, L.; Calabró, A.; Balbo, A.L.; Del Panno, M.T.; Mac Cormack, W.P. Hydrocarbon removal and bacterial community structure in on-site biostimulated biopile systems designed for bioremediation of diesel-contaminated Antarctic soil. Polar Biol. 2014, 38, 677-687. [CrossRef]

46. Aislabie, J.M.; Novis, P.M.; Ferrari, B. Microbiology of eutrophic (ornithogenic and hydrocarbon-contaminated) soil. In Antarctic Terrestrial Microbiology: Physical and Biological Properties of Antarctic Soils; Cowan, D.A., Ed.; Springer: Berlin/Heidelberg, Germany, 2014; pp. 91-113. [CrossRef]

47. Rizzo, C.; Malavenda, R.; Gerçe, B.; Papale, M.; Syldatk, C.; Hausmann, R.; Bruni, V.; Michaud, L.; Giudice, A.L.; Amalfitano, S. Effects of a Simulated Acute Oil Spillage on Bacterial Communities from Arctic and Antarctic Marine Sediments. Microorganism 2019, 7, 632. [CrossRef]

48. Dias, R.L.; Ruberto, L.; Hernández, E.; Vázquez, S.C.; Balbo, A.L.; Del Panno, M.T.; Mac Cormack, W.P. Bioremediation of an aged diesel oil-contaminated Antarctic soil: Evaluation of the "on site" biostimulation strategy using different nutrient sources. Int. Biodeterior. Biodegrad. 2012, 75, 96-103. [CrossRef]

49. Ruberto, L.; Dias, R.; Balbo, A.L.; Vazquez, S.; Hernandez, E.; Mac Cormack, W. Influence of nutrients addition and bioaugmentation on the hydrocarbon biodegradation of a chronically contaminated Antarctic soil. J. Appl. Microbiol. 2009, 106, 1101-1110. [CrossRef]

50. Bhattacharya, M.; Guchhait, S.; Biswas, D.; Datta, S. Waste lubricating oil removal in a batch reactor by mixed bacterial consortium: A kinetic study. Bioprocess Biosyst. Eng. 2015, 38, 2095-2106. [CrossRef]

51. Höckenreiner, M.; Neugebauer, H.; Lakshmanan, E. Ex situ bioremediation method for the treatment of groundwater contaminated with PAHs. Int. J. Environ. Sci. Technol. 2013, 12, 285-296. [CrossRef]

52. Chikere, C.B.; Okoye, A.U.; Okpokwasili, G.C. Microbial community profiling of active oleophilic bacteria involved in bioreactorbased crude-oil polluted sediment treatment. J. Appl. Environ. Microbiol. 2016, 4, 1-20. [CrossRef]

53. Ibrahim, S.; Zahri, K.N.M.; Convey, P.; Khalil, K.A.; Gomez-Fuentes, C.; Zulkarnain, A.; Alias, S.A.; González-Rocha, G.; Ahmad, S.A. Optimisation of biodegradation conditions for waste canola oil by cold-adapted Rhodococcus sp. AQ5-07 from Antarctica. Electron. J. Biotechnol. 2020, 48, 1-12. [CrossRef]

54. Abdulrasheed, M.; Zulkharnain, A.; Zakaria, N.N.; Roslee, A.F.A.; Khalil, K.A.; Napis, S.; Convey, P.; Gomez-Fuentes, C.; Ahmad, S.A. Response Surface Methodology Optimization and Kinetics of Diesel Degradation by a Cold-Adapted Antarctic Bacterium, Arthrobacter sp. Strain AQ5-05. Sustainability 2020, 12, 6966. [CrossRef]

55. Roslee, A.F.A.; Zakaria, N.N.; Convey, P.; Zulkharnain, A.; Lee, G.L.Y.; Gomez-Fuentes, C.; Ahmad, S.A. Statistical optimisation of growth conditions and diesel degradation by the Antarctic bacterium, Rhodococcus sp. strain AQ5-07. Extremophiles 2019, 24, 277-291. [CrossRef] [PubMed] 
56. Mohan, S.V.; Sirisha, K.; Rao, N.C.; Sarma, P.; Reddy, S.J. Degradation of chlorpyrifos contaminated soil by bioslurry reactor operated in sequencing batch mode: Bioprocess monitoring. J. Hazard. Mater. 2004, 116, 39-48. [CrossRef] [PubMed]

57. Rayner, J.L.; Snape, I.; Walworth, J.L.; Harvey, P.M.; Ferguson, S.H. Petroleum-hydrocarbon contamination and remediation by microbioventing at sub-Antarctic Macquarie Island. Cold Reg. Sci. Technol. 2007, 48, 139-153. [CrossRef]

58. Emiliano, H.; Peixoto, R.S. Bioremediation in Antarctic Soils. J. Pet. Environ. Biotechnol. 2015, 6. [CrossRef]

59. Wu, G.; Coulon, F.; Yang, Y.-W.; Li, H.; Sui, H. Combining Solvent Extraction and Bioremediation for Removing Weathered Petroleum from Contaminated Soil. Pedosphere 2013, 23, 455-463. [CrossRef]

60. Malavenda, R.; Rizzo, C.; Michaud, L.; Gerçe, B.; Bruni, V.; Syldatk, C.; Hausmann, R.; Giudice, A.L. Biosurfactant production by Arctic and Antarctic bacteria growing on hydrocarbons. Polar Biol. 2015, 38, 1565-1574. [CrossRef]

61. Fu, P.; Secundo, F. Algae and their bacterial consortia for soil bioremediation. Chem. Eng. Trans. 2016, 49, 427-432. [CrossRef]

62. Aislabie, J.; Saul, D.J.; Foght, J.M. Bioremediation of hydrocarbon-contaminated polar soils. Extremophiles 2006, 10, 171-179. [CrossRef]

63. Ibrahim, S.; Khalil, K.A.; Zahri, K.N.M.; Gomez-Fuentes, C.; Convey, P.; Zulkharnain, A.; Sabri, S.; Alias, S.A.; GonzálezRocha, G.; Ahmad, S.A. Biosurfactant Production and Growth Kinetics Studies of the Waste Canola Oil-Degrading Bacterium Rhodococcus erythropolis AQ5-07 from Antarctica. Molecules 2020, 25, 3878. [CrossRef] [PubMed]

64. Timmis, K.N. (Ed.) Handbook of Hydrocarbon and Lipid Microbiology; Springer: Berlin/Heidelberg, Germany, 2010; pp. 2313-2325. [CrossRef]

65. Haritash, A.; Kaushik, C. Biodegradation aspects of Polycyclic Aromatic Hydrocarbons (PAHs): A review. J. Hazard. Mater. 2009, 169, 1-15. [CrossRef] [PubMed]

66. Chavan, A.; Mukherji, S. Effect of co-contaminant phenol on performance of a laboratory-scale RBC with algal-bacterial biofilm treating petroleum hydrocarbon-rich wastewater. J. Chem. Technol. Biotechnol. 2010, 85, 851-859. [CrossRef]

67. Van Epps, A. Phytoremediation of Petroleum Hydrocarbons; U.S. Environmental Protection Agency: Washington, DC, USA, 2006.

68. Frick, C.M.; Farrell, R.E.; Germida, J.J. Assessment of Phytoremediation as an In-Situ Technique for Cleaning Oil-Contaminated Sites; Petroleum Technology Alliance of Canada (PTAC): Calgary, AB, USA, 1999; Available online: https:/ / pdfs.semanticscholar.org/ 28e1/c0f93e89b5d8aefe87de9acf0d9999c20b6b.pdf?_ga=2.102329097.900078707.1557136094-1748355359.1521921840 (accessed on 10 October 2020).

69. Semple, K.T.; Cain, R.B.; Schmidt, S. Biodegradation of aromatic compounds by microalgae. FEMS Microbiol. Lett. 1999, 170, 291-300. [CrossRef]

70. Lei, A.-P.; Hu, Z.-L.; Wong, Y.-S.; Tam, N.F.-Y. Removal of fluoranthene and pyrene by different microalgal species. Bioresour. Technol. 2007, 98, 273-280. [CrossRef] [PubMed]

71. Todd, S.J.; Cain, R.B.; Schmidt, S. Biotransformation of naphthalene and diaryl ethers by green microalgae. Biodegradation 2002, 13, 229-238. [CrossRef] 